\title{
Considerations in the valuation of urban green space: accounting for user participation
}

\begin{abstract}
Within the ecosystem services framework, valuations of natural capital have primarily taken a landscape-scale approach. The generation of transferable monetary values for individual ecosystems has likewise depended on assessments carried out at large spatial scales. Such methods, however, lack adequate regard for the complex natural habitats. This complexity is heightened in urban areas where green spaces provide multiple services according to use and participation. Hence, there is a need to acknowledge the unique value of urban nature, and the socially-mediated nature of its productivity. This need was addressed through a study of collectively managed green spaces in a north-west England conurbation (UK). Ninety-one sites were identified, followed by a case study of twelve sites assessing their value across four ecosystem services. A subsequent projection of the value of stakeholder-led land management was calculated and compared to an existing reference for the value of urban green space from the The Economics of Ecosystems and Biodiversity database. The study found that collectively managed sites contribute considerable added-value to urban natural capital. In addition, the work highlights the shortcomings of applying transferable values to multi-functional habitat types, calling for a closer consideration of social-ecological contexts in the valuation of ecosystem services.
\end{abstract}

\subsection{Introduction}

Since the idea of placing value on the services provided by nature from both economic (Westman 1977) and utilitarian (Ehrlich and Ehrlich, 1981) perspectives was proposed in the late twentieth century, the concept of ecosystem services has developed into a major framework for the promotion and design of regional, national and global environmental management (CBD, 2004; MEA, 2005; UK NEA, 2011). The Ecosystem Approach (CBD, 2004) adopted the notion in the fifth of its twelve principles, placing emphasis on the importance, and value, of those services which are derived from the wide range of global and local habitats and ecosystems (MEA, 2005; Bennett et al., 2009; Niemelä et al., 2010; Maes et al., 2012; Mouchet et al., 2014). The ecosystem services framework was further developed and promoted by the Millennium Ecosystem Assessment (MEA, 2005) which sought to categorise and measure the current and historical health of the world's ecosystems with an emphasis on the implications for human health and well-being. The concept continues to take precedence in national and international ecological assessments (TEEB, 2008; UK NEA, 2011; Haines-Young and Potschin, 2013) as well as in research exploring issues in environmental governance, human well-being and biodiversity (e.g. Von Shirnding, 2002; Burls and Khan, 2005; Worm et al., 2006; Costanza et al., 2007; Pudup, 2008; Niemelä et al., 2010; Mace et al., 2012; Wall and Nielsen, 2012).

It has been asserted in the literature that assessments of ecosystem services across spatial scales must take into consideration the multifunctional and complex nature of natural habitats and, therefore, the goods and benefits they provide (Niemelä et al., 2010; Norgaard, 2010; UK NEA, 2011). Understanding the co-production of ecosystem services in highly complex social-ecological systems demands both a site-specific and landscapescale approach to habitat assessments (UK NEA, 2011). The opportunities and challenges associated with the co-management of multiple ecosystem services have been described through the identification of positive (win-win) and negative (win-lose) relationships between specific services (e.g. Raudsepp-Hearne et al., 2010; Howe et al., 2014; Dennis and James, 2016a).

Despite the majority of the world's population now living in towns and cities (United Nations, 2008), urban areas have been under-acknowledged in global and regional assessments of ecological capital. The authors of the Millennium Ecosystem Assessment (2005) chose largely to ignore the urban landscape and the World Development Report (United Nations, 2008), while focussing on urban areas, did not touch upon the subject of urban ecosystems in any form. More recently, patterns in the production of urban ecosystem services have been explored (e.g. Niemelä et al., 2010; Haase et al., 2012), though these have largely taken a landscapebased approach. Accordingly, much of the work carried out on urban ecosystem services does not honour the complexity of the urban habitat mosaic. In order to evaluate the productivity and value of urban nature, the identification of ecosystem services at the landscape scale must be married to a smaller scale appreciation of the productivity and use of green spaces in cities. 
Attempts to integrate nature conservation into planning and policy have led to the establishment of the field of ecological economics (Costanza et al., 1997) with the aim of incentivising and mainstreaming greater consideration of the environment towards development which is both economically and ecologically sustainable. The Ecosystem Approach was put forward as a lucid, practical framework, where necessary, adopting a monetary approach to managing ecosystems at various scales (MEA, 2005). Attempts have since been made to flesh out the promising conceptual elements of the Millennium Ecosystem Assessment into a working methodology for environmental accounting and management to protect and enhance global and local ecosystem services (e.g. Mace et al., 2012; Maes et al., 2012). Perhaps the most comprehensive of these has been The Economics of Ecosystems and Biodiversity (TEEB) program, a global-scale initiative that seeks to produce research on the economic and environmental costs of ecosystem and biodiversity degradation with the intention of informing decision-makers at all levels (TEEB, 2008). The TEEB initiative is married closely to the notion of natural capital and the use of economic methods and proxies to value, and thereby manage, ecosystem services more effectively and realistically. The designation of transferable economic values to natural resources is aimed at providing a working appreciation of the role of such capital towards human wellbeing (Daly and Farley, 2004) as well as functional valuation approaches to ecosystem goods and benefits (Costanza et al., 2006). In this respect, urban areas, largely due to their inherent complexity, have been continuously overlooked.

\subsection{The value of green space and civic ecological movements in urban areas}

Although urban relevant ecosystem services have been described and categorised according to recognised international classifications (e.g., Bolund and Hunhammar, 1999; Niemelä et al., 2010; Elmqvist et al., 2013) such studies have largely taken a landscape-scale approach. Likewise, the valuation of ecosystem services in urban areas has been projected through highly generalised approaches such as the use of secondary data and spatial modelling (e.g. Konopacki and Akbari, 2000; Costanza et al, 2006; Jim and Chen, 2009; Peng, 2012; Gómez-Baggethun and Barton, 2013). The TEEB database compiled by Van der Ploeg and De Groot (2010) is one of the few attempts to place a coherent, transferable value on urban green space. This database provides a figure for total economic value of urban green space as the sum of the contribution of this habitat type to climate regulation, recreation and water regulation (based on a study by Brenner-Guillermo, 2007). Again, a landscape-scale approach was employed and, hitherto, studies which offer a detailed economic account of the functionality of the current array of multi-functional and multi-use urban green space types have not been forthcoming.

The main findings of the UK NEA (2011) include the importance of nature in meeting existence and value "needs" of human beings where contemporary consumption practices have failed. In particular, interaction with and recreation in nature were highlighted in the report as significant contributors to human health and well-being. The report states that "a key knowledge gap regarding education and ecological knowledge goods concerns the processes by which adults acquire ecological knowledge, their participation in nature-based educational activities and how knowledge acquisition is influenced by engagement with environmental settings as a form of cultural service" (UK NEA, 2011, p.83). Despite this assertion, and that the report also highlights, and recommends, increasing public participation in the management of ecosystems, the influence of user participation in natural resource management on the value of ecosystem services was not acknowledged.

The lack of consideration given to the effect of social mediation in the production of ecosystem services is conspicuous in other efforts to evaluate urban ecological capital (Constanza et al., 2006; Peng 2012; GómezBaggethun and Barton, 2013). Although urban residents are usually seen solely as the recipients of the ecosystem services provided by natural elements within the landscape (Krasny and Tidball, 2015) they represent a key functional ingredient of urban social-ecological systems. Research into civic ecological movements has demonstrated that stakeholder stewardship of natural resources in urban areas can lead to significant gains in terms of ecosystem services production (Krasny and Tidball, 2015; Dennis and James, 2016a) and governance (Ernstson et al., 2008) but studies have neglected to investigate the implications of such socialecological action in terms of value added to urban green space. Studies have shown that the production of a range of ecosystem services increases proportional to user participation in the management of urban green commons (Dennis and James 2016a) and that human and environmental health present a significant level of 
interdependence (Burls, 2005; Bird, 2007; Fuller et al., 2007; Dennis and James 2016b). Little work has been conducted, however, which seeks to place meaningful monetary values on urban green space in which socialecological interactions are heightened through user participation in its management.

The civic stewardship of natural resources, particularly in urban areas, has become an important topic of research in its own right with studies disentangling the various potential benefits in the form of food security (Metcalf and Widener, 2011); improved diet (Alaimo et al., 2008; Kazmierczak et al., 2013); participant health (Hynes and Howe, 2004; Pudup, 2008); reduced crime (Kuo et al., 1998; 2001); sense of place (Krasny and Tidball, 2015) and social capital (Okvat and Zautra, 2011) as well as adding to and preserving local ecological memory (Barthel et al., 2010). Policy statements have likewise asserted the contribution to be made by stakeholder-led stewardship to green infrastructure and ecosystem services in the urban landscape (Defra, 2011; UK NEA, 2011). The positive effects of green space as a buffer against the stresses of urban living and as a boon for human well-being have been well documented (De Vries et al., 2003; Mitchell and Popham, 2007; Tzoulas et al., 2007; Hartig et al., 2014) and research suggests that interaction with, and cultivation of, green space is particularly beneficial to participant health (Townsend, 2006; Wakefield et al., 2007; Okvat and Zautra, 2011; Tidball and Stedman, 2013, Krasny and Tidball, 2015).

Such positive effects may be due to the particular physical activities which take place in, for example, collectively managed gardens. Francis (1987) first highlighted that community managed spaces offered alternative activities to those available in municipal city parks and that such activities were particularly attractive to certain user groups. Moreover, community gardens encouraged continuing participation and place attachment amongst users. The specific benefits arising from such common natural assets have still not been effectively addressed in terms of the production and valuation of ecosystem services. A more in-depth approach to assessing and valuing such services may reveal them to be significant in terms of planning and environmental accounting in urban green space design.

In order to address this issue, a case study was designed and implemented to quantify the value of stakeholdermanaged green space in a north-west England conurbation. The study comprised three adjoining metropolitan districts in the Greater Manchester area (UK): Manchester, Salford and Trafford. These three areas comprise the urban centre of the Greater Manchester conurbation and contain multiple examples of collectively managed urban green space (AfSL, n.d.; Kindling Trust, 2015; Dennis et al., 2016a; 2016b; Dennis and James, 2016b). Such activity stems from precedents of social-ecological activism in the area reaching back to the beginning of the industrial era (Ritvo, 2010). The three districts comprising the study area are presented in the context of the Greater Manchester area and green space cover across the study area is mapped in Figure 1. 


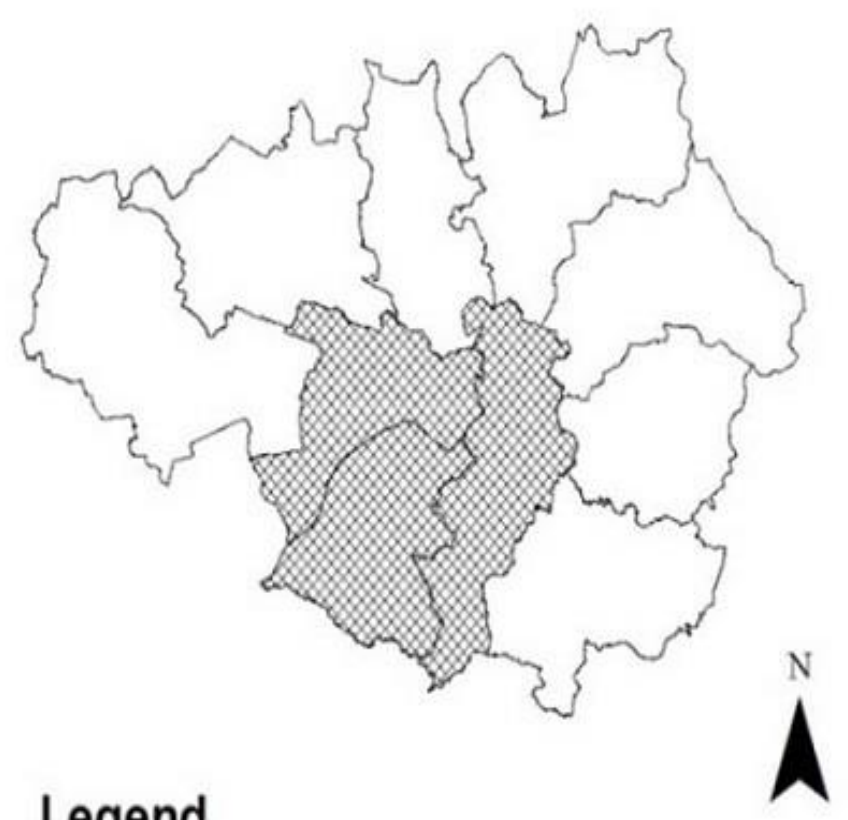

Legend

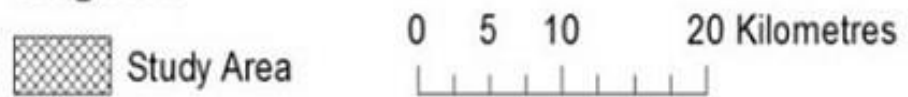

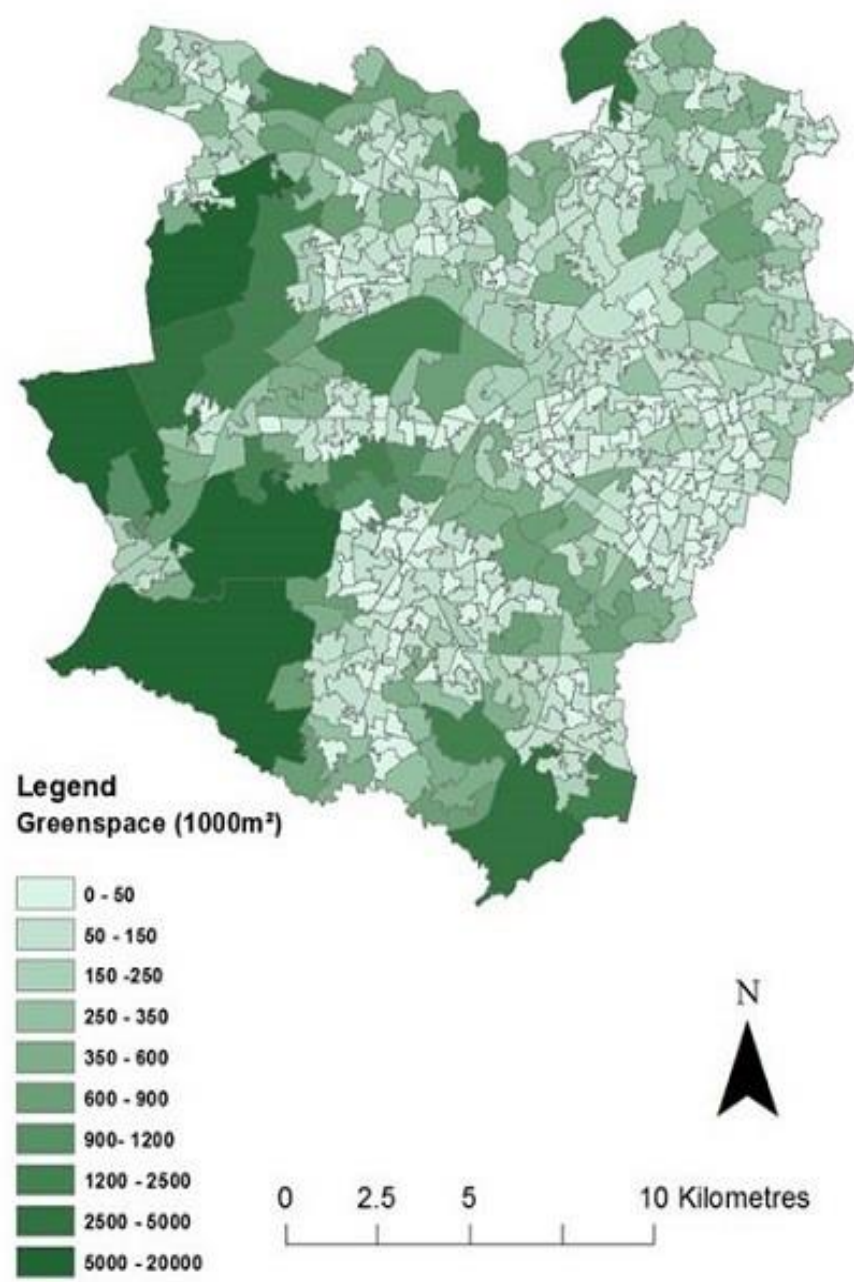

Figure 1 Study area districts and green space cover (ONS, 2001)

Collectively-managed pockets of green space were identified within the landscape and a case study of 12 sites was carried out to assess productivity across four urban-relevant ecosystem services. Values were assigned to these goods and benefits, based on proxies obtained from appropriate literature and market sources. The monetary values resulting from the case study were then projected to give an indication of the total contribution of collectively managed green spaces to the value of ecosystem services in the wider landscape.

\subsection{Methods}

An assessment of the value of communally managed spaces in the study area was calculated through a fourstep process. Firstly, sites of collectively managed green space in the three municipal districts comprising the study area were identified using a snowball sampling method (after Goodman, 1961). The second step of the assessment consisted of a case study comprising three established examples of each of the four horticulture based types, evaluating the productivity of each site in terms of ecosystem services. In the third stage of the evaluation process, values were applied to each of the goods and services issuing from the twelve sites using proxy measures obtained from associated literature and, where applicable, relevant market values. These values were then projected for the study area as a whole based on the total number of sites recorded in step one. Finally, in order to evaluate the contribution of such stakeholder-led green space management, the total economic value (TEV) of urban green space according to the TEEB valuation database (Van de Ploeg and De Groot, 2010) was used as a reference (inflated to 2015 values).

\subsection{Identification of collectively managed green spaces}

A snowball sampling exercise was carried out which spanned a period of two years (July 2012 - July 2014) until data saturation was reached. A total of 91 sites were recorded in the data collection process. Resulting from 
the identification and mapping of collectively managed sites in the study area, a typology consisting of four main approaches to the cultivation and management of sites were observed:

\section{a) Community gardens}

Areas of public green space which are maintained by members of the community for a range of activities and social provision, a proportion of which is often centred on gardening for food but with a range of additional structures and facilities which serve priorities such as leisure and educational activities, social interaction, and provision of communal open spaces.

\section{b) Community allotments}

Pre-existing or adapted plots on established allotment gardens which have been designated by local authorities as areas for use by the wider community, primarily for food production and related educational activities.

\section{c) Community orchards}

Areas of land managed by local residents and volunteers dedicated primarily to the cultivation of hard and soft fruits. Set in areas of extensive recreational public green space.

\section{d) Pocket parks}

Sites occurring in areas of high surface sealing achieving their impact by maximising the use of limited available top soil and using an innovative array of container planting and other improvised naturalistic features such as green roofs and walls.

In addition to these horticultural initiatives there existed a number of sites which were not primarily land-based but which consisted of premises or mobile projects which served as hubs of environmental information, training or resources. Some of these sites also exhibited small-scale therapeutic or educational horticultural activities as a secondary service or as satellite projects. Many projects were, however, purely "office-based" and, in some cases, multiple projects were housed in the same building. Therefore, sites falling into this category, although providing local services were not included in the assessment and valuation of specifically ecosystem services. The locations of the twelve case study sites are presented in Figure 2.

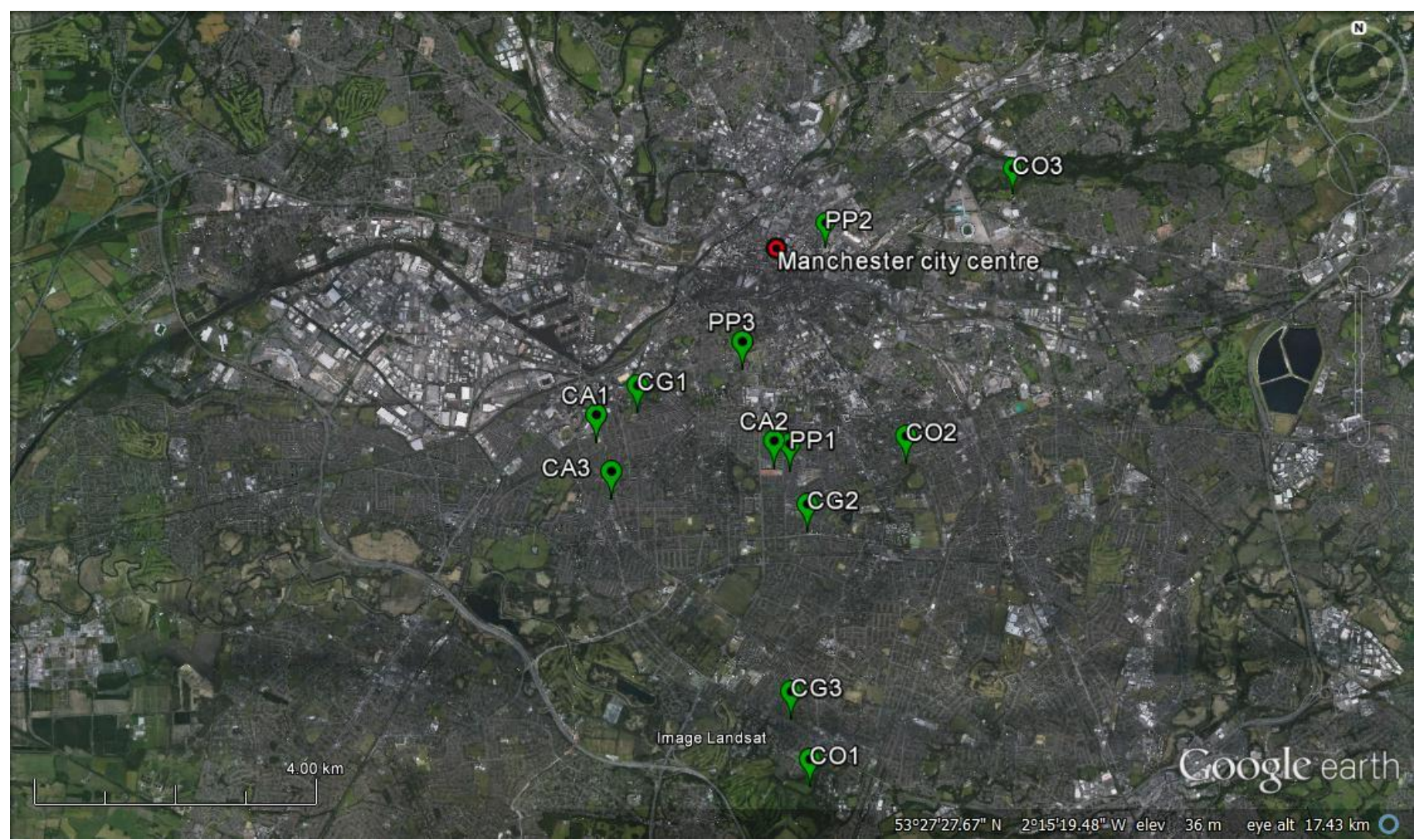




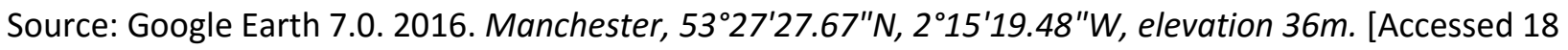
February 2016]. Available from: http://www.google.com/earth/index.html

\subsection{Ecosystem service assessments}

Twelve sites were selected from those identified in step one, comprising 3 from each type defined through the snowball sampling process. This provided a suitable sample size (13 percent of the total number of collectively managed sites identified in the study area) from which to extrapolate ecosystem service valuations. The mean output of all twelve sites was calculated as a value $100 \mathrm{~m}^{-2} \mathrm{yr}^{-1}$ and this was then applied, based on mean case study site size, to the total number of sites mapped in the study area. To provide a realistic estimate, the final result was weighted by the respective frequency of each type recorded which permitted a projected total value of collectively managed spaces in the study area.

Four urban-relevant ecosystem services were selected for assessment based on their prominence in the relevant literature. These were: microclimate regulation (Bolund and Hunhammer, 1999, Van der Ploeg and De Groot, 2010; Aubry et al., 2012), food yield (Barthel et al., 2011; Krasny and Tidball, 2015), volunteer hours (Natural England, 2014; Krasny and Tidball, 2015) and therapeutic benefit (Hansmann et al., 2007; Krasny and Tidball, 2009; UK NEA, 2011). Although recreational services are regularly cited as key ecosystem services derived from urban green space (Bolund and Hunhammar, 1999; Pretty et al., 2005; 2007 Bird, 2007; Tzoulas et al., 2007; Niemelä et al., 2010), they are often loosely, and variably, defined. Bolund and Hunhammar (1999) describe them simply as opportunities for play and rest whereas Niemelä et al. (2010) include a range of activities such as nature observation, education, photography, hunting, swimming and fishing. The broad interpretability of recreational activities attached to ecosystems has been acknowledged (Daniel et al., 2012) and suggests that this category of services does not offer a comprehensive description of the specific activities taking place at, for example, collectively managed gardens. For example, the horticulture orientated management of the latter promotes a certain form of physical activity which provides both a service in itself, leading to the cultivation and beautification of local spaces (Svendsen and Campbell, 2008; Krasny and Tidball, 2015) whilst, simultaneously, bringing participants physical and mental benefits. These latter include gains such as improved nutrition (Wakefield et al., 2007), increased activity (Hynes and Howe, 2004), lessened anxiety (Wood et al., 2015) and physical and mental restoration (Söderback et al., 2004) derived from gardening and social interaction specific to sites of communal green space (Francis, 1987; Pudup, 2008; Okvat and Zautra, 2011). To reflect this dual role of community input in urban green commons, the value of volunteer hours, invested in the management of community assets, were recognised and included in the assessment along with that of the therapeutic benefits to participant well-being. This was done in lieu of a simplistic evaluation of such outdoor activity as recreation.

Assessment methods were adapted from those used in a previous exploration of stakeholder stewardship in urban ecosystem services (Dennis and James, 2016a). Monetary values were acquired by selecting proxies from the relevant available literature and applying them to case study site characteristics. Details of assessments and valuation calculations are presented by individual ecosystem service.

\subsubsection{Microclimate regulation}

An assessment of site contribution to microclimate regulation was achieved using the Green Infrastructure Toolkit developed by Green Infrastructure North-west in the UK (GINW, 2010). The tool is based on the premise of calculating the area of a given site which can be said to be ecologically effective (Krause, 2011). Weightings are assigned to each category of 14 discrete surface cover types, reflecting levels of vegetative cover and permeability. The weightings range from scores of $0-1.4 \mathrm{~m}^{-2}$ as a reflection of their ecological integrity and values are then summed to provide an overall score in square metres as the ecologically effective area of the site.

\subsubsection{Food yield}


In order to estimate the rate of production of vegetable crops at case study sites, a proxy was used based on detailed harvest reports that had been carried out across community gardening sites in Philadelphia, Camden (Penn.) and Trenton (NJ), in the United States. The reports were compiled by the Urban Agriculture and Community Food Security research group, directed by the University of Pennsylvania. The proxy was acquired by taking mean yields per unit site area under cultivation at community-managed vegetable gardens in the Philadelphia Harvest Report (Vitiello and Nairn, 2009) and applying this factor to the case-study sites selected for this study. In the case of orchards and other sites partially designated to fruit production, projected yields were calculated using data taken from the UK government Basic Horticultural Statistics dataset (Defra, 2013). Mean yield per square metre was calculated for UK commercial yields (2007 - 2011: Defra, 2013) for both orchard and soft fruit. These were then used as proxies according to cultivation regimes observed at case study sites. Data were gathered concurrently with those for microclimate regulation which involved accurate measurement of site dimensions and land-cover (April to September 2013).

\subsubsection{Volunteer hours}

Data on volunteer hours per month during the growing season (March to October (DECC, 2013)) were gathered as a measure of community involvement at each of the 12 sites from site facilitators or, where this role was not explicit, from prominent site users. Volunteer hours relating specifically to physical activity were recorded; data relating to administration activities were not included in the analysis. These data were then employed in both the valuation of volunteer hours and the therapeutic benefits stemming from horticultural activity. These data were collected over the period of March 2013 to December 2013.

\subsection{Ecosystem service valuation}

\subsubsection{Microclimate regulation}

Proxy values for services contributing to microclimate regulation were taken from the urban green space habitat of the TEEB database (Van de Ploeg and De Groot, 2010). Specifically, the US Dollars hectare ${ }^{-1} \mathrm{yr}^{-1}$ values were obtained for water and climate regulation. These figures were converted into GBP $100 \mathrm{~m}^{-2} \mathrm{yr}^{-1}$. Values for urban green space in the TEEB database were in the 2004 dollar value which was translated into GBP for the same year using data from the New York Federal Reserve Bank historical foreign exchange data (Federal Reserve Bank of New York, 2014). The result was then converted into a value for 2015 using the Bank of England Inflation Calculator (Bank of England, 2015). Accordingly, the TEEB value of US\$ $845 \mathrm{ha}^{-1} \mathrm{yr}^{-1}$ was converted to GBP $461 \mathrm{ha}^{-1} \mathrm{yr}^{-1}$ using the 2004 currency exchange rate (mean available 10 am exchange rates 01.01.2004 to 31.12.2004). This value was then translated to a 2015 value of $£ 6.38100 \mathrm{~m}^{-2} \mathrm{yr}^{-1}$. This figure was subsequently applied to the total site area which was deemed to be ecologically effective according to the rationale of the Green Infrastructure toolkit used in the microclimate regulation assessment. The resulting value reflected the valuation potential of each site according to the climate and water regulatory benefits of urban green space as outlined by Van der Ploeg and De Groot (2010).

\subsubsection{Food yield}

Values for yields in GBP kg-1 were calculated separately for vegetable crops, soft fruit and hard fruit. Values for vegetable crops were taken from the University of Pennsylvania's harvest report based on community gardens in the city of Philadelphia (Vitiello and Nairn, 2009), upon which values for case study site yields were also based. Valuation of vegetable crops in the Philadelphia Harvest Report (PHR) was established upon prices of comparable produce for sale at local farmers markets as opposed to supermarket goods (Vitiello and Nairn, 2009). This reflected the small-scale and largely organic nature of the cultivation process in community gardens. These particular characteristics of gardens in the Philadelphia study were shared by the case studies sites in this study and as such values from the Philadelphia research were used as a proxy for vegetable crops. These values were consistent across all scales of gardening assessed in the areas of Philadelphia as well as in Trenton and Camden (NJ) where the harvest report was replicated. Figures applied in the Philadelphia Harvest Report, for all gardens below half an acre $\left(<2000 \mathrm{~m}^{2}\right)$ were at a ratio of $\$ 2.31 \mathrm{lb}^{-1}$. Pounds were converted to kilograms and the 2008 US Dollar value was converted to GBP for the same year and re-calculated, allowing for 
inflation, to a corresponding 2015 value as for the TEEB values. The resulting amount gave an indication of vegetable crops as being worth $£ 3.30 \mathrm{~kg}^{-1}$. Values for soft and hard fruit yields were sourced from current (October 2014) retail values for organic produce using apples as a proxy for hard fruit and raspberries as the soft fruit proxy. Prices were obtained from 8 local retailers ( 4 from local wholefood outlets and 4 from popular supermarket chains). Values were acquired from price-comparison websites where available (Mysupermarket Ltd., 2014), independent retailer websites (Carey Organic, 2014; Limited Resources, 2014; Northern Harvest, n.d.), and from in-store visits (Unicorn Grocery Ltd). This was done in order to reflect the availability of produce in the local area and to obtain a realistic appreciation of market value. The mean of these values was then taken as the proxy for use in the study valuation. The mean retail price for apples was $f 3.85 \mathrm{~kg}^{-1}$ and, for raspberries, $f 18.29 \mathrm{~kg}^{-1}$ (Table 1). The total figure for site yield was then calculated using the above proxy values and used as an estimate of yearly harvest value.

Table 1 Local retail prices for fruit produce (Oct. 2014)

\begin{tabular}{|lrr|}
\hline Retail Outlet & $\begin{array}{c}\text { Apples } \\
\text { (organic, in } \mathbf{f} \mathbf{~ k g}^{-\mathbf{1}} \text { ) }\end{array}$ & $\begin{array}{r}\text { Raspberries } \\
\text { (organic, } \mathbf{i n} \mathbf{f} \mathbf{~ k g}^{\mathbf{}} \mathbf{} \text { ) }\end{array}$ \\
Carey Organic & 3.50 & 16.00 \\
Northern Harvest & 3.50 & 16.00 \\
Unicorn Grocery & 3.00 & 16.00 \\
Limited Resources & 3.50 & $\mathrm{n} / \mathrm{a}$ \\
Tesco & 3.80 & 20.00 \\
Morrisons & 4.50 & 20.00 \\
Sainsbury's & 4.50 & 20.00 \\
ASDA & 4.50 & 20.00 \\
Mean & 3.85 & $\mathbf{1 8 . 2 9}$ \\
\hline
\end{tabular}

\subsubsection{Volunteer hours}

In order to appreciate the value of volunteer input as a tangible contribution to sense of place and maintenance of pooled resources, a value was obtained in the form of an hourly rate of earnings based on figures from the Office for National Statistics (ONS, 2013) as recommended by the local NGO (NonGovernmental Organisation) Manchester Community Development Foundation (MCDF). In their published guidance for community groups seeking funding for local regeneration projects, as part of a nationwide government-led initiative, the MCDF places a value of $f 11.09$ on every volunteer hour figured into governmentmatched bids (Manchester Community Central, n.d.). This figure, according to the MCDF publication, is taken from the Office for National Statistics' Annual Survey of Hours and Earnings, as the median gross hourly earnings rate. This value was ratified against the most recent 2013 data from the Office for National Statistics (ONS, 2013) which offered a median rate of $£ 13.13$ per hour and a mean of $£ 15.87$ for full-time employees. The figures for part-time employees were $f 8.29$ (median) and $f 11.18$ (mean). Given that the level of volunteer input at the case study sites reflected most accurately part-time working hours, values for this category of earnings were considered in the analysis. Furthermore, the median was taken as being the more conservative estimate given that the mean value occurred between the $70^{\text {th }}$ and $75^{\text {th }}$ percentile for national earnings, suggesting that this value may have been distorted by very high earning occupations in the dataset. The median was therefore more indicative of a typical UK wage and this figure was subsequently applied to total monthly volunteer hours and used to give an annual total value.

\subsubsection{Therapeutic benefits}

Previous studies have reported the benefits to mental well-being issuing from outdoor activities as a form of eco-therapy (Relf, 2005; Corazon et al., 2012; Bishop and Purcell, 2013). The efficacy of such effects has been equated to that of professional counselling (D'Augelli and Hershberger, 1993) and the value of horticulture as therapy has been estimated at rate of $f 40$ hour $^{-1}$ as the equivalent average cost of a professional counselling session (Munoz and Nimegeer, 2012). This figure was applied to the number of monthly volunteer hours recorded at communal sites and projected to give a yearly total value. 
Biodiversity was not entered separately into the monetary valuation analysis. The principal reason for this was that the standard method for valuing biodiversity as a service in its own right has been largely derived, in the field of ecological economics, from its contingent value, primarily through willingness to pay scenarios. It was not possible to provide a comprehensive account of the total contribution to biodiversity potential by case study sites using proxies from such valuation methods.

\subsection{Valuation calculation}

The four valuation estimates detailed above were then summed to give a combined economic value for each of the twelve sites. In order to arrive at an estimate of the total economic value of sites across the entire study area, the mean value was derived for the case study sites as economic output $100 \mathrm{~m}^{-2}$.

This figure was subsequently used to estimate the total collective value of sites recorded in the mapping exercise. This was calculated by taking the mean site area for each type in the case study and multiplying the

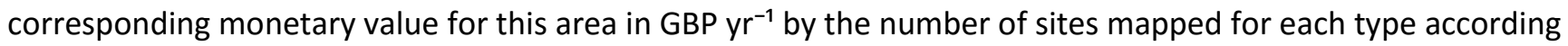
to the following equation:

Type value $=\left(\frac{\text { Mean type area }\left(\mathrm{m}^{2}\right)}{100 \mathrm{~m}^{2}} \times\right.$ type mean value per $\left.100 \mathrm{~m}^{2}\right) \times$ total type frequency

Values for each type were then summed to give a projected total value of collectively managed sites in the study area.

The TEV for urban green space per unit area was used as a reference for comparison with that calculated for the case study. The total value of green space in the study area landscape was calculated by applying the TEEB valuation database TEV for urban green space (converted and inflated as for TEEB microclimate regulation values) to data on green space cover obtained from the UK Office for National Statistics' generalised land use database (GLUD: ONS, 2005). This estimate of the TEV of green space in the study area as a whole was compared to that projected for all community-managed green commons identified in the snowball sampling exercise.

\subsection{Results}

Data on monetary values of site production for the selected ecosystem services are summarised in Table 2

Table 2 Summary of monetary valuation of site service provision

\begin{tabular}{|c|c|c|c|c|c|c|c|c|}
\hline Site & $\begin{array}{c}\text { Site } \\
\text { Area } \\
\mathrm{m}^{2} \\
\end{array}$ & $\begin{array}{c}\text { Ecologically } \\
\text { Effective } \\
\text { Area } \mathrm{m}^{2} \\
\end{array}$ & $\begin{array}{c}\text { Microclimate } \\
\text { regulation } \\
£ \mathrm{yr}^{-1 *}\end{array}$ & $\begin{array}{c}\text { Yield } \\
\text { f summer } \\
-1 \\
\end{array}$ & $\begin{array}{c}\text { Volunteer } \\
\text { Hours- } \\
£ \mathrm{yr}^{-1+} \\
\end{array}$ & $\begin{array}{l}\text { Therapeutic } \\
\text { Value } f \mathrm{yr}^{-1}\end{array}$ & $\begin{array}{l}\text { Gross total } \\
\quad £ \mathrm{yr}^{-1}\end{array}$ & $\begin{array}{c}\mp 100 \mathrm{~m}^{-2} \\
\mathrm{yr}^{-1}\end{array}$ \\
\hline CG1 & 936 & 665 & 31 & 873 & 2653 & 12800 & 16,368 & 1749 \\
\hline CG2 & 1530 & 1316 & 61 & 1830 & 19100 & 92160 & 113,174 & 7397 \\
\hline CG3 & 560 & 554 & 26 & 2293 & 13264 & 64000 & 79,592 & 14213 \\
\hline CA1 & 950 & 703 & 32 & 9101 & 14590 & 70400 & 94,136 & 9909 \\
\hline CA2 & 780 & 616 & 28 & 6980 & 19896 & 96000 & 122,915 & 15758 \\
\hline CA3 & 630 & 422 & 19 & 4170 & 13264 & 64000 & 81,461 & 12930 \\
\hline CO1 & 1044 & 1190 & 55 & 2472 & 1326 & 6400 & 10,274 & 984 \\
\hline $\mathrm{CO} 2$ & 1734 & 1994 & 92 & 8723 & 5306 & 25600 & 39,756 & 2293 \\
\hline $\mathrm{CO}$ & 380 & 456 & 21 & 3840 & 10081 & 48640 & 62,590 & 16471 \\
\hline PP1 & 215 & 133 & 6 & 1074 & 9948 & 48000 & 59,030 & 27456 \\
\hline PP2 & 221 & 104 & 5 & 1734 & 2918 & 14080 & 18,739 & 8479 \\
\hline PP3 & 217 & 130 & 6 & 658 & 13264 & 64000 & 77,930 & 35912 \\
\hline
\end{tabular}




\section{* Based on TEEB urban green space climate and water regulation +Projected for UK growing season Mar-Oct}

Table 3 presents the projected area cover and value of the four site types and the total value of collectively managed sites in the study area weighted by the recorded frequency of each type.

Table 3 Frequencies and calculated value of collectively managed sites by type

\begin{tabular}{|c|c|c|c|c|c|}
\hline Site type & Frequency* & $\begin{array}{l}\text { Mean site } \\
\text { area }\left(m^{2}\right)^{+}\end{array}$ & $\begin{array}{l}\text { Projected } \\
\text { total area } \\
\left(\mathrm{m}^{2}\right)\end{array}$ & $\begin{array}{l}\text { Mean value } \\
\left(£ 100 \mathrm{~m}^{-2}\right. \\
\left.\text { year }^{-1}\right)\end{array}$ & $\begin{array}{l}\text { Total projected } \\
\text { value } f \mathrm{yr}^{-1}\end{array}$ \\
\hline $\begin{array}{l}\text { Community } \\
\text { garden }\end{array}$ & 40 & 1009 & 40347 & 7786 & 3141470 \\
\hline $\begin{array}{l}\text { Community } \\
\text { allotment }\end{array}$ & 23 & 787 & 18093 & 12866 & 2327871 \\
\hline Pocket park & 15 & 218 & 3265 & 23949 & 781939 \\
\hline $\begin{array}{l}\text { Community } \\
\text { orchard }\end{array}$ & 13 & 1053 & 13685 & 6583 & 900814 \\
\hline Total & 91 & 829 & 75390 & $9487^{*}$ & $7,152,094$ \\
\hline $\begin{array}{l}\text { Study area } \\
\text { total }\end{array}$ & - & - & $149,228,480$ & $46.17^{a}$ & $68,898,789$ \\
\hline
\end{tabular}

*Total count for study area

${ }^{+}$Based on case study site data

* Mean weighted by type frequency

${ }^{a}$ Calculated using TEEB value for urban green space TEV

The values in Table 3 give an estimated value of the selected ecosystem services produced by the case studies as $f 7,152,094$. Given that the estimated total area of such spaces in the study area $\left(75,390 \mathrm{~m}^{2}\right)$ equalled only $0.05 \%$ of the total figure for non-domestic green space $\left(149,228,480 \mathrm{~m}^{2}\right)$, the respective monetary value equated to a considerable proportion (10.38\%) of the total economic value estimated, using only TEEB values $\left(£ 4617 \mathrm{ha}^{-1} \mathrm{yr}^{-1}\right)$, of green space for the study area $\left(£ 68,898,789 \mathrm{yr}^{-1}\right)$.

\subsection{Discussion}

Previous attempts to quantify the value of urban green space have relied primarily on the application of proxies derived from secondary datasets employed through landscape-scale assessments (e.g. Konopacki and Akbari, 2000; Costanza et al, 2006; Jim and Chen, 2009; Peng, 2012). As such, detailed appraisals of the productivity of multi-functional pockets of green space in the urban environment, particularly where user participation is a mediating factor (UK NEA, 2011; Dennis and James, 2016a), have been lacking. Furthermore, natural resources are more limited in urban areas than any other global habitat (Krasny and Tidball, 2015) and as a result human and environmental health in such areas are closely coupled phenomena (MEA, 2005; WHO, 2005; Ernstson et al., 2008; Coutts, 2011; Dennis and James, 2016b). The aim of this study was therefore to permit a more detailed assessment of the value of urban green space by focussing on the multiple, and socially mediated, end uses of collectively managed urban green commons.

\subsection{Value added to urban ecosystem services by stakeholder participation in green space management}

In terms of value added by the presence of collectively managed spaces, the impact of such innovative, community-led management of common green space (primarily due to gains in food yield and volunteer input from the presence of urban agriculture) resulted in a considerable increase from the baseline TEV figure (from Van der Ploeg and De Groot, 2010) of $£ 46.17100 \mathrm{~m}^{-2} \mathrm{yr}^{-1}$ to an estimated $£ 9487100 \mathrm{~m}^{-2} \mathrm{yr}^{-1}$ (Table 3). Much of the value added to collectively managed spaces stemmed from the positive feedbacks resulting from user participation. The dual value of volunteer input as both a contribution to site cultivation whilst simultaneously comprising an end-use in itself, as horticultural therapy, must however be treated with caution given that little is known on the long-term efficacy of horticultural approaches to therapy. For example, Barton and Pretty (2010) found that health benefits were detectable through as little as five minutes exposure to natural environments and a study by Wood et al. (2015) suggested that a variety of gains to participant health as a 
result of allotment gardening were not significantly affected by the length of time spent on the activity. Therefore, the treatment of each hour of participation as being the therapeutic equivalent of one hour of professional counselling, although supported by previous studies (D'Augelli and Hershberger, 1993; Corazon et al., 2012; Munoz and Nimegeer, 2012) may require clarification through further research. Furthermore, although the majority of participation at case study sites was concentrated at regular organised sessions, cultivation was also carried out by individuals outside of such structured times and information on the exact length of time spent by users per visit was not collected.

Nonetheless, the analyses presented here demonstrate that stakeholder-led green space management in the study area made a significant positive contribution to the ability of open spaces to produce urban-relevant ecosystem services. If data on the total economic value of green space provided by the TEEB database (as the sum value of climate regulation, water attenuation and recreation) are to be taken as an accepted baseline, then participatory approaches to local green space management, as described herein, constitute highly valuable elements of social-ecological capital in relation to this baseline (Table 3 ).

The potential for increasing the social-ecological value of green space in urban areas is, for the services studied in this report, largely due to the goods and benefits which are the result of community-led urban agriculture: namely, food yield, social-ecological intensification of sites and the value derived from local volunteer involvement. Such benefits are not universally associated with urban green space in general, for example, in the assessments produced by (and partially employed in the monetary evaluation in this study) the TEEB research program (Van der Ploeg and De Groot, 2010). However, such beneficial outcomes are, as derived from the practice of food cultivation, the cornerstone of community-led greening and gardening (Hynes and Howe, 2004).

It must be stated also, that although the services selected for study were those which were most pertinent to the urban context and, as such, provided a useful measure of the potential of community greening, they were not exhaustive in describing the potential for services which may otherwise issue from such practices. For example, food production provides a service in itself but has associated benefits such as the preservation of genetic diversity, heirloom crop varieties, and social-ecological memory, for example, across generations (Barthel et al., 2010) as well as by-products in the form of useable organic materials (e.g. compost, mulch, organic fertilisers). Urban agriculture also has the potential to bring about gains by way of maintenance of soil nutrient levels, diversity of soil micro-organisms and the phytoremediation of low ecological quality, derelict or contaminated land (Khan, 2005). The potential value of biological diversity present on collectively managed site was also absent from the assessment due to the poor transferability of current available valuation methods. Recent research has highlighted the high degree of biodiversity present within domestic gardens (Thompson et al., 2003; Goddard et al., 2010; 2013; Cameron et al., 2012), allotments (Speak et al., 2015) and other improvised green space types (Orsini et al., 2014; Lin et al., 2015), as well as the positive effect of user participation on biological and structural diversity (Dennis and James, 2016b). In light of such findings, the value of collectively managed urban land may be considerably higher than that which has been possible to describe here. Suffice to say that the projected value of green commons produced in the assessment, given the above caveats, is likely to be conservative in nature.

\subsection{Social-ecological considerations in the evaluation of natural capital in urban areas}

It is important to note that "green space", as defined in the Office for National Statistics Generalised Land Use Database (GLUD) used in the mapping study and employed in the valuation estimates, included a variety of green space types as a single category. These included, for example, allotment gardens, cemeteries, corporateowned land, city parks and urban farmland, among others, which due to variations in management, vegetative structure and use will lead to differential productivity in terms of ecosystem services provision not captured in the GLUD data. Likewise, the TEEB values employed in the assessment did not take full consideration of the multi-purpose nature of urban green space. The TEEB database values for urban green space were derived from a single study (Brenner-Guillermo, 2007) which took a landscape-scale approach and thereby failed to acknowledge the complexity and multi-functionality of diverse urban green spaces. As such, the monetary values of green space in the study area calculated based on the GLUD, and using TEEB figures, are to be treated with caution. 
The study therefore highlights the challenges and uncertainties involved in the valuation of urban green space through secondary data. Clearly the large discrepancy in the area-standardised values observed between green space (based on the TEEB proxy value), and collectively managed sites (Table 3), not only underlines the multifunctional and highly productive nature of the latter but the necessity for ecological economics to acknowledge the multi-use status of natural habitats. Whereas, monetary values applied to larger, more coherent habitat types and biomes such as wetlands and grasslands may be more readily transferable, natural resources in closely coupled social-ecological systems, due to their inherent complexity, clearly require a more detailed evaluation. Although such an approach would demand much increased input in terms of resources, given that most of the world's population now live in urban areas, a more in-depth investigation into the value of diverse urban land use is perhaps warranted. Moreover, ecosystem services within urban social-ecological systems can be highly mediated by social inputs (Ernstson et al., 2008; Barthel et al., 2010; Ernstson et al., 2010) and a true appreciation of the role and value of natural capital in cities must seek to integrate and understand the interactions between social and ecological capital in the productivity of urban landscapes. In the case of collective management of green space by stakeholders, social actors provide the context, impetus, and the knowledge and energy inputs for local ecosystem management, whilst simultaneously comprising the beneficiaries of the outputs in terms of ecosystem services. Such positive feedbacks, which influence the environment and lived experience of urban residents, have been hitherto largely ignored by government planning policy statements and methods of ecosystem service valuation.

By demonstrating that social-ecological innovation generates such positive feedbacks in terms of effective green space management and the production of a range of ecosystem services, this study has highlighted the need to re-consider, and value, the potential contribution of semi-formal resource governance as part of an urban planning framework. Clearly, a re-appreciation of the multi-purpose, heterogeneous qualities within the mosaic of urban green space is required in order to arrive at adequate valuation and planning methodologies (CABE, 2010; CIWEM; 2015). Notwithstanding the shortcomings of the available data, the analysis illustrated the degree of value added to urban natural capital by the social-ecological intensification which results from the collective management of green common spaces.

\subsection{Conclusions}

The study revealed that significant gains in social-ecological capital are to be made through the collaborative management of pockets of green space in urban areas. A key factor in the generation of added value by such involvement was the presence of positive feedbacks which are derived from community input. The combined value of community voluntarism and the therapeutic benefits stemming from participation added considerably to the relative value of such spaces and support the argument that the productivity of urban green space can be mediated by social inputs to desirable effect. The study also highlighted the shortcomings in the application of transferable values for those habitats such as urban green space which exhibit a high degree of diversity in terms of function, use and management. A more sensitive approach to the valuation of particularly urban habitats should therefore be encouraged in order to reach a more comprehensive valuation of the natural capital embedded in those areas which are home to the majority of the global population. By taking a more sophisticated and use-sensitive approach to the value of pockets of urban green space, such as that demonstrated in this study, stakeholders and planning authorities alike should be better able to account for, and promote best practice in, the use and designation of urban natural capital.

\section{References}

AfSL (Action for Sustainable Living) n.d.. Funders - See who funds our work and projects. [online] Available at: http://www.afsl.org.uk/about/funders/ (accessed 15 Jan. 2015).

Alaimo, K., Packnett, E., Miles, R. and Kruger, D. 2008. Fruit and vegetable intake among urban community gardeners. Journal of Nutrition, Education and Behavior 40(2): 94-101. 
Aubry, C., Ramamonjisoa, J, Dabat, M., Rakotoarisoa, J., Rakotondraibe, J., Rabeharisoa, L. 2012. Urban agriculture and land use in cities: An approach with the multi-functionality and sustainability concepts in the case of Antananarivo (Madagascar). Land Use Policy. 29(2): 429-239.

Bank of England. 2015. Bank of England / Education and Museum / Resources / Inflation Calculator. [online] Available at:

http://www.bankofengland.co.uk/education/Pages/resources/inflationtools/calculator/flash/default.aspx [Accessed 27 Jan. 2015].

Barthel, S., Folke, C. and Colding, J. 2010. Social-ecological memory in urban gardens: retaining the capacity for management of ecosystem services. Global Environmental Change. 20(2): 255-265.

Barthel, S., Sorlin, S. and Ljungkvist, J. 2011. Innovative Memory and Resilient Cities: Echoes from Ancient Constantinople. In: P.J.J. Sinclair, ed. 2010. The Urban Mind: Cultural and Environmental Dynamics.Uppsala. Uppsala University Press.

Bennet, E. M., Peterson, G. D., and Gordon, L. J. 2009. Understanding relationships among multiple ecosystem services. Ecology Letters. 12: 1 -11.

Bird, W. 2007. Natural Thinking: Investigating the link between the Natural Environment, Biodiversity and Mental Health. London: Royal Society for the Protection of Birds.

Bishop, R. and Purcell, E., 2013. The value of an allotment group for refugees. The British Journal of Occupational Therapy. 76(6): 264-269.

Bolund, P. and Hunhammar, S. 1999. Ecosystem services in urban areas. Ecological Economics. 29: 293-301.

Brenner-Guillermo, J. 2007. Valuation of ecosystem services in the Catalan coastal zone. Marine Sciences, Polytechnic University of Catalonia.

Burls, A. and Khan, W. 2005. Human health and nature conservation. The British Medical Journal. 331: 1221.

CABE (Commission for Architecture and the Built Environment). 2010. Community green: using local spaces to tackle inequality and improve health. London. CABE.

Cameron, R., Blanusa, T., Taylor, J., Salisbury, A., Halstead, A., Henricot, B. and Thompson, K. 2012. The domestic garden: its contribution to urban green infrastructure. Urban Forestry and Urban Greening. 11(2): 129-137

Carey Organic. 2014. [online] Available at: http://www.whitethornfarm.co.uk/careyorganicfarmshop.pdf [Accessed 24 Oct. 2014].

CBD (Convention on Biological Diversity). 2004 The Ecosystem Approach, (CBD Guidelines). Montreal. Secretariat of the Convention on Biological Diversity.

CIWEM (Chartered Institution of Water and Environmental Management). 2015. Multi-Functional Urban Green Infrastructure. [online] London: CIWEM. Available at:

http://www.ciwem.org/FileGet.ashx?id=1875\&library=Public\%20Access.

Corazon, S., Stigsdotter, U., Moeller, M. and Rasmussen, S. 2012. Nature as therapist: Integrating permaculture with mindfulness- and acceptance-based therapy in the Danish Healing Forest Garden Nacadia. European Journal of Psychotherapy \& Counselling. 14(4): 335-347. 
Costanza, R., d'Arge, R., de Groot, R., Farber, S., Grasso, M., Hannon, B., Limburg, K., Naeem, S., O'Neill, R., Paruelo, J., Raskin, R., Sutton, P. and van den Belt, M. 1997. The value of the world's ecosystem services and natural capital. Nature. 387(6630): 253-260.

Costanza, R., Wilson, M., Troy, A., Voinov, A., Liu, S., and D'Agostino, J. 2006. The Value of New Jersey's Ecosystem Services and Natural Capital. NJ. New Jersey Department of Environmental Protection

Costanza, R., Fisher, B., Ali, S., Beer, C., Bond, L., Boumans, R., Danigelis, N., Dickinson, J., Elliott, C., Farley, J. and Gayer, D. 2007. Quality of life: An approach integrating opportunities, human needs, and subjective wellbeing. Ecological economics. 61(2): 267-276.

Coutts, C. 2011. Putting the Capital "E" Environment into Ecological Models of Health. Journal of Environmental Health. 74(4): 26-29.

Daly, H. and Farley, J., 2004. Ecological economics: principles and practice. Washington, DC. Island Press.

Daniel, T., Muhar, A., Arnberger, A., Aznar, O., Boyd, J., Chan, K., Costanza, R., Elmqvist, T., Flint, C., Gobster, P. and Grêt-Regamey, A., 2012. Contributions of cultural services to the ecosystem services agenda. Proceedings of the National Academy of Sciences. 109(23): 8812-8819.

D'Augelli, A. and Hershberger, S. 1993. Lesbian, gay, and bisexual youth in community settings: Personal challenges and mental health problems. American Journal of Community Psychology. 21(4): 421-448.

DECC (Department for Energy and Climate Change). 2013. Thermal Growing Season in Central England. London. DECC.

Defra (Department for the Environment, Food and Rural Affairs). 2011. The Natural Choice: Securing the Value of nature. London. Defra.

Defra (Department for the Environment, Food and Rural Affairs). 2013. Basic Horticultural Statistics 2013 [computer file]. London. Defra. Downloaded from:

https://www.gov.uk/government/uploads/system/uploads/attachment_data/file/141609/hort-dataset31jul13.xls.

Dennis, M., Armitage, R. and James, P. 2016a. Urban Ecosystems. doi:10.1007/s11252-016-0551-3

Dennis, M., Armitage, R. and James, P. 2016b. Appraisal of social-ecological innovation as an adaptive response by stakeholders to local conditions: Mapping stakeholder involvement in horticulture orientated green space management. Urban Forestry \& Urban Greening. 18: 86-94.

Dennis, M. and James, P. 2016a. Site-specific factors in the production of local urban ecosystem services: A case study of community-managed green space. Ecosystem Services. 17: 208-216.

Dennis, M. and James, P. 2016b. User participation in urban green commons: Exploring the links between access, voluntarism, biodiversity and well being. Urban Forestry \& Urban Greening. 15: 22-31.

De Vries, S., Verheij, R., Groenewegen, P. and Spreeuenberg, P. 2003. Natural environments - healthy environments? An exploratory analysis of the relationship between greenspace and health. Environment and Planning. 35: 1717-1731.

Ehrlich, P and Ehrlich, A. 1981. Extinction: the causes and consequences of the disappearance of species. New York. Random House. 
Elmqvist, T., Fragkias, M., Goodness, J., Güneralp, B., Marcotullio, P., McDonald, R., Parnell, S., Schewenius, M., Sendstad, M., Seto, K. and Wilkinson, C. eds. 2013. Urbanization, biodiversity and ecosystem services: challenges and opportunities: a global assessment. Dordrecht. Springer.

Ernstson, H., Barthel, S., Andersson, E. and Borgström, S. 2010. Scale-crossing brokers and network governance of urban ecosystem services: the case of Stockholm. Ecology and Society. 15(4): 28. Available at: http://www.ecologyandsociety.org/vol15/iss4/art28/

Ernstson, H., Sörlin, S. and Elmqvist, T. 2008. Social movements and ecosystem services-the role of social network structure in protecting and managing urban green areas in Stockholm. Ecology and Society. 13(2): 39. Available at: http://www.ecologyandsociety.org/vol13/iss2/art39/

Federal Reserve Bank of New York. 2014. Foreign Exchange Rates Historical Search - Federal Reserve Bank of New York. [online] Available at: http://www.newyorkfed.org/markets/fxrates/historical/home.cfm [Accessed 27 Oct. 2014].

Francis, M. 1987. Meanings attached to a city park and a community garden in Sacramento. Landscape Research. 12(1): 8-12.

GINW (Green Infrastructure North West). 2010. Green Infrastructure Toolkit [computer file]. Downloaded from: http://www.ginw.co.uk/resources/gi_toolkit.xls

Goddard, M., Dougill, A. and Benton, T. 2010. Scaling up from gardens: biodiversity conservation in urban environments. Trends in Ecology \& Evolution. 25(2): 90-98.

Goddard, M., Dougill, A. and Benton, T. 2013. Why garden for wildlife? Social and ecological drivers, motivations and barriers for biodiversity management in residential landscapes. Ecological Economics. 86: 258273.

Gómez-Baggethun, E. and Barton, D. 2013. Classifying and valuing ecosystem services for urban planning. Ecological Economics. 86: 235-245.

Goodman, L. 1961. Snowball Sampling. Annals of Mathematical Statistics. 32(1): 148-170.

Haase, D., Scwarz, N., Strohbach, M., Kroll, F., Seppelt, R. 2012. Synergies, Trade-offs, and Losses of Ecosystem Services in Urban Regions: an Integrated Multiscale Framework Applied to the Leipzig-Halle Region, Germany. Ecology and Society. 17(3): 22.

Haines-Young, R. and Potschin, M. 2013. Common International Classification of Ecosystem Services (CICES): Consultation on Version 4, August-December 2012. EEA Framework Contract No EEA/IEA/09/003. Available at: http://www.cices.eu or www.nottingham.ac.uk/cem

Hansmann, R., Hug, S. and Seeland, K. 2007. Restoration and stress relief through physical activities in forests and parks. Urban Forestry \& Urban Greening. 6(4): 213-225.

Hartig, T., Mitchell, R., de Vries, S. and Frumkin, H. 2014. Nature and Health. Annual Review of Public Health. 35: 207-228.

Howe, C. Suich, H., Vira, B. and Mace, G. 2014. Creating win-wins from trade-offs? Ecosystem services for human well-being: A meta-analysis of ecosystem service trade-offs and synergies in the real world. Global Environmental Change. 28: 263 -275.

Hynes, H. and Howe, G. 2004. Urban horticulture in the contemporary United States: personal and community benefits. Acta Horticulturae. 643: 171-181. DOI: 10.17660/ActaHortic.2004.643.21 
Jim, C. and Chen, W., 2009. Ecosystem services and valuation of urban forests in China. Cities. 26(4): 187-194.

Kazmierczak, A., Connelly, A., and Sherriff, G. 2013. Growing Manchester Programme Final Evaluation Report. Manchester: University of Manchester Press.

Khan, A. 2005. Role of soil microbes in the rhizospheres of plants growing on trace metal contaminated soils in phytoremediation. Journal of Trace Elements in Medicine and Biology. 18(4): 355-364.

Kindling Trust. 2015. Funders \& Supporters The Kindling Trust. Available at: http://kindling.org.uk/funderssupporters [accessed 15 Jan. 2015].

Konopacki, S. and Akbari, H., 2000. Energy savings calculations for heat island reduction strategies in Baton Rouge, Sacramento and Salt Lake City. Berkeley. Lawrence Berkeley National Laboratory.

Krasny, M. and Tidball, K. 2009. Community Gardens as Contexts for Science, Stewardship, and Civic Action Learning. Cities and the Environment. 2(1): 8.

Krasny, M. and Tidball, K. 2015. Civic Ecology: Adaptation and Transformation from the Ground Up. Cambridge, MA: MIT Press.

Krause, A. 2011. GRaBS Expert Paper 6: The Green Space Factor and the Green points System. London. Town and Country Planning Association.

Kuo, F., Bacaicoa, M. and Sullivan, W. 1998. Transforming inner-city landscapes: trees, sense of safety and preference. Environment and Behavior. 30(1): 28-59.

Kuo, F. and Sullivan, W. 2001. Environment and crime in the inner city: does vegetation reduce crime? Environment and Behaviour. 33: 343-367.

Limited Resources. 2014. organic fruit delivery. [online] Available at: http://limited-resources.co.uk/organicfruit/ [Accessed 24 Oct. 2014].

Lin, B., Philpott, S. and Jha, S. 2015. The future of urban agriculture and biodiversity-ecosystem services: challenges and next steps. Basic and Applied Ecology. 16(3): 189-201.

Mace, G., Norris, K. and Fitter, A. 2012. Biodiversity and ecosystem services: a multilayered relationship. Trends in Ecology and Evolution. 27(1): 19-26.

Maes, J., Egoh, B., Willemen, L., Liquete, C., Vihervaara, P., Schagner, J. P., Grizzetti, B., Drakou, E. G., La Notte, A., Zulian, G., Faycal, B., Paracchini, M. L., Braat, L. and Bidoglio, G. 2012. Mapping ecosystem services for policy support and decision making in the European Union. Ecosystem Services. 1: 31 -39.

Manchester Community Central. [no date]. Guidance Notes: How to request funds from the panel. [online] Available at:

https://www.manchestercommunitycentral.org/sites/manchestercommunitycentral.co.uk/files/Moss\%20Side \%20Community\%20First\%20Grant\%20Guidance\%20Notes.pdf

MEA (Millenium Ecosystem Assessment). 2005. Ecosystems and Human Well-being: Health Synthesis. Washington D.C. Island Press.

Metcalf, S., and Widener, M. 2011. Growing Buffalo's Capacity for Local Food. Applied Geography. 31(4): 124251. 
Mitchell, R. and Popham, F., 2007. Greenspace, urbanity and health: relationships in England. Journal of Epidemiology and community health. 61(8): 681-683.

Mouchet, M. A., Lamarque, P., Martın-Lopez, B., Crouzat, E., Gos, P., Byczek, C. and Lavorel, S. 2014. An interdisciplinary methodological guide for quantifying associations between ecosystem services. Global Environmental Change. 28: 298 - 308.

Munoz, S. and Nimegeer, A. 2012. Evaluating and Measuring the Impact of Health Promotion Activities in Hospital Grounds. [online] Inverness. Centre for Rural Health, University of the Highlands and Islands. Available at: http://www.uhi.ac.uk/en/research-enterprise/res-themes/health/Guide-for-Drawing-on-the-Principles-ofSocial-Return-on-Investment.pdf

Mysupermarket, 2014. [online] Available at: http://www.mysupermarket.co.uk/ [Accessed 24 Oct. 2014].

Natural England. 2014. Indicator: S\&E06_S: Number of volunteer hours on NIA activity. Available at: http://nia.naturalengland.org.uk/protocols/S\&E06_S.pdf (accessed 14 September 2015).

Niemelä, J., Saarela, S., Söderman, T., Kopperoinen, L., Yli-Pelkonen, V.,Väre, S. and Kotze, D. 2010. Using the ecosystem services approach for better planning and conservation of urban green spaces: a Finland case study. Biodiversity and Conservation. 19(11): 3225-3243.

Norgaard, R. B. 2010. Ecosystem services: From eye-opening metaphor to complexity blinder. Ecological Economics. 69(6): $1219-1227$.

Northern Harvest Ltd. [no date]. Organic food delivery - Cheshire, Lancashire, Manchester \& Liverpool from Northern Harvest UK. [online] Available at: http://www.northernharvest.co.uk/ [Accessed 24 Oct. 2014].

Okvat, H. and Zautra, A. 2011. Community gardening: a parsimonious path to individual, community, and environmental resilience. American Journal of Community Psychology. 47(3-4): 374-387.

ONS (Office for National Statistics). 2001 Census: Digitised Boundary Data (England and Wales) [computer file]. UK Data Service Census Support. Downloaded from: http://edina.ac.uk/census Licensed under the terms of the Open Government Licence [http://www.nationalarchives.gov.uk/doc/open-government-licence/version/2].

ONS (Office for National Statistics). 2005. Generalised land use database statistics for England [computer file]. London. Downloaded from: http://data.gov.uk/dataset/land_use_statistics_generalised_land_use_database Licensed under the terms of the Open Government Licence [http://www.nationalarchives.gov.uk/doc/opengovernment-licence/version/3].

ONS (Office for National Statistics). 2013. Annual Survey of Hours and Earnings, 2013 Provisional Results. [online] Available at: http://www.ons.gov.uk/ons/publications/re-reference-tables.html?edition=tcm\%3A77328216 [Accessed 24 Sep. 2014].

Orsini, F., Gasperi, D., Marchetti, L., Piovene, C., Draghetti, S., Ramazzotti, S., Bazzocchi, G. and Gianquinto, G. 2014. Exploring the production capacity of rooftop gardens (RTGs) in urban agriculture: the potential impact on food and nutrition security, biodiversity and other ecosystem services in the city of Bologna. Food Security. 6(6): 781-792.

Peng, K. 2012. Urban Greenspace Distribution and their Eco-Service Valuation Evaluation for Yangtze River Delta. Advanced Materials Research. 610-613: 862-867.

Pretty, J., Peacock, J., Hine, R., Sellens, M., South, N. and Griffin, M. 2007. Green exercise in the UK countryside: effects on health and psychological well-being, and implications for policy and planning. Journal of Environmental Planning and Management. 50(2): 211-231. 
Pretty, J., Peacock, J., Sellens, M. and Griffin, M. 2005. The mental and physical health outcomes of green exercise. International Journal of Environmental Health Research. 15(5): 319-337.

Pudup, M. 2008. It takes a garden: cultivating citizen-subjects in organized garden projects. Geoforum. 39(3): $1228-1240$.

Raudsepp-Hearne, C., Peterson, G. D. and Bennett, E. M. 2010. Ecosystem service bundles for analyzing tradeoffs in diverse landscapes. Proceedings of the National Academy of Sciences. 107(11): 5242-5247.

Relf, P. 2005. The therapeutic values of plants. Pediatric Rehabilitation. 8(3): 235-237.

Ritvo, H. 2010. The Dawn of Green: Manchester, Thirlmere and Modern Environmentalism. Chicago: University of Chicago Press.

Söderback, I., Söderström, M. and Schälander, E., 2004. Horticultural therapy: the 'healing garden' and gardening in rehabilitation measures at Danderyd Hospital Rehabilitation Clinic, Sweden. Pediatric rehabilitation. 7(4): 245-260.

Speak, A., Mizgajski, A. and Borysiak, J. 2015. Allotment gardens and parks: provision of ecosystem services with an emphasis on biodiversity. Urban Forestry and Urban Greening.

http://dx.doi.org/10.1016/j.ufug.2015.07.007

Svendsen, E. and Campbell, L. 2008. Urban ecological stewardship: understanding the structure, function and network of community-based urban land management. Cities and the Environment (CATE). 1(1): 4.

TEEB (The Economics of Ecosystems and Biodiversity). 2008. An Interim Report. Wesseling. European Communities.

Thompson, K., Austin, K., Smith, R., Warren, P., Angold, P. and Gaston, K. 2003. Urban domestic gardens (I): Putting small-scale plant diversity in context. Journal of Vegetation Science. 14(1): 71.

Tidball, K. and Stedman, R. 2013. Positive dependency and virtuous cycles: from resource dependence to resilience in urban social-ecological systems. Ecological Economics. 86: 292-299.

Townsend, M. 2006. Feel blue? Touch green! Participation in forest/woodland management as a treatment for depression. Urban Forestry and Urban Greening. 5(3): 111-120.

Tzoulas, K., Korpela, K., Venn, S., Yli-Pelkonen, V., Kaźmierczak, A., Niemelä, J. and James, P. 2007. Promoting ecosystem and human health in urban areas using Green Infrastructure: a literature review. Landscape and Urban Planning. 81(3): 167-178.

UK NEA (United Kingdom National Ecosystem Assessment). 2011. UK National Ecosystem Assessment: Understanding Nature's Value to Society. Technical Report. Cambridge. UNEP-WCMC.

United Nations, Department of Economic and Social Affairs. 2008. World Urbanisation Prospects: 2007 Revision. New York. United Nations.

Van der Ploeg, S. and De Groot, R. 2010. The TEEB Valuation Database - a searchable database of 1310 estimates of monetary values of ecosystem services. Wageningen. The Netherlands. Foundation for Sustainable Development.

Vitiello, D. and Nairn, M. 2009. Community Gardening in Pennsylvania. 2008 Harvest Report. [online] Philadelphia. University of Pennsylvania. Available at: 
https://docs.google.com/viewer?a=v\&pid=sites\&srcid=ZGVmYXVsdGRvbWFpbnxoYXJ2ZXNOcmVwb3JOc2IOZXxn eDozYjA2ZDZjM2M2YmUyYTYw [Accessed 5 Sep. 2012].

Von Shirnding, Y. 2002. Health and sustainable development: can we rise to the challenge? The Lancet. 360(9333): 632-637.

Wakefield, S., Yeudall, F., Taron, C., Reynolds, J. and Skinner, A. 2007. Growing urban health: community gardening in South-East Toronto. Health Promotion International. 22(2): 92-101.

Wall, D. and Nielsen, U. 2012. Biodiversity and ecosystem services: is it the same below ground? Nature Education Knowledge. 3(12): 8.

Westman, 1977. How much are nature's services worth? Science. 197: 960-964.

WHO (World Health Organisation). 2005. Ecosystems and Human Well-Being. Health Synthesis. Geneva. WHO.

Wood, C.J., Pretty, J. and Griffin, M., 2015. A case-control study of the health and well-being benefits of allotment gardening. Journal of Public Health. doi: 10.1093/pubmed/fdv146

Worm, B., Barbier, E., Beaumont, N., Duffy, J., Folke, C., Halpern, B., Jackson, J., Lotze, H., Micheli, F., Palumbi, S., Sala, E., Selkoe, K., Stachowicz, J. and Watson, R. 2006. Impacts of biodiversity loss on ocean ecosystem services. Science. 314(5800): 787-790. 